\title{
Justyna Szymańska
}

\section{Popfeminizm w służbie rewolucji. Ruchy kobiece i praktyki protestu na przykładzie ukraińskiej grupy Femen}

\section{Wstęp}

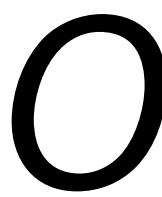

ur God is woman, our mission is protest, our weapons are bare breasts!', My Body My Weapon ${ }^{2}$. Tak brzmią niektóre hasła wypisane na ścianach kijowskiej siedziby ukraińskiego ruchu Femen, od kilku lat znanego w całej Europie dzięki temu, że jego uczestniczki protestują nago. Aktywistki Femenu rozpoczynały swoją działalność jako oddolny ruch, którego celem jest polityczny protest przeciwko wszechobecnemu w Ukrainie seksizmowi i dyskryminacji kobiet, a także nadużyciom władzy. Dzisiaj są gwiazdami i ulubienicami europejskich mediów, a szczególną sławą cieszą się w Paryżu, który wybrały na miejsce swojego "międzynarodowego obozu treningowego nowych feministek"

Początki ruchu sięgają roku 2008. Wtedy to młode dziewczyny - obecne liderki Femenu: Anna Hucoł, Sasza Szewczenko, Inna Szewczenko oraz Oksana Saczko - zebrały się, by razem walczyć o prawa kobiet, sprzeciwiać się seksistowskiej polityce ukraińskich władz, protestować przeciw stereotypowemu postrzeganiu kobiet w życiu publicznym. Wyrażały to w skandalizujący, bardzo medialny sposób. Ich działania nie miały precedensu w życiu publicznym Ukrainy, więc każde ich pojawienie się z kolejną akcją na ulicy lub w telewizji wywoływało niemałe zainteresowanie. Rzeczą niespotykaną było dotąd, by w ramach

\footnotetext{
1 ang. „Naszym Bogiem jest kobieta, naszą misją protest, naszą bronią nagi biust!”

2 ang. "Moje ciało moją bronią"

${ }^{3}$ jak tę inicjatywę ochrzciła prasa, np. Femen's topless warriors start boot camp for global feminism, "The Guardian", http:// www.guardian.co.uk/world/2012/sep/22/femen-topless-warriors-global-feminism („Femen's topless warriors start boot camp for global feminism", b.d.)
} 
protestu na ulicę wychodziły młode dziewczyny, do tego - niemal nagie. Wiele osób do dziś nie interesuje się tym, o co Femen walczy lub przeciw czemu protestuje, kojarzą go jedynie z nagością. Ponieważ większość moich badań etnograficznych odbywała się w Kijowie, mogłam nie tylko skontaktować się z samymi członkiniami Femenu, ale też z ludźmi, którzy mieli okazję widzieć niektóre ich akcje na żywo: zarówno z ich zwolennikami, jak i przeciwnikami. Badania terenowe prowadziłam w ciągu kilku miesięcy w roku 2012 i 2013, przede wszystkim w Kijowie, ale również w Warszawie i Paryżu. Oparłam je na metodzie pogłębionego wywiadu swobodnego (IDI), przede wszystkim zaś na obserwacji uczestniczącej ${ }^{4}$. Miałam okazję przebywać w ówczesnej siedzibie Femenu w Kijowie (oraz jeden raz w Paryżu, już po opuszczeniu przez femenki kraju) i obserwować codzienną rutynę aktywistek. Przeprowadziłam wiele rozmów zarówno z obecnymi i byłymi członkiniami Femenu, jak i z osobami związanymi z grupą; ich kolegami i koleżankami ze studiów, z pracy, współlokatorkami, sympatykami oraz krytykami. Oprócz dziewczyn bezpośrednio związanych z Femenem skupiłam się przede wszystkim na mieszkańcach Kijowa, jako pierwszych odbiorcach ich akcji w przestrzeni miejskiej - w przeważającej większości młodych ludziach, studentach lub niedawnych absolwentach. Na początku działalności Femenu, gdy żył nim cały Kijów, to doświadczenie było często przywoływane przez mieszkańców w rozmowach, które prowadziłam. Sława gwiazd nie przylgnęła jednak do femenek natychmiast - działaczki musiały przebyć długą drogę od lokalnej grupy protestu do pełnoprawnego ruchu o zasięgu globalnym.

Co wyróżnia więc Femen spośród wielu innych grup, co sprawiło, że to właśnie on stał się rozpoznawalną marką, wyrazistym podmiotem na europejskiej mapie zbiorowych działań oddolnych? Warto zastanowić się nad zakreśleniem pola podmiotowości owego bytu, który w skali Europy Wschodniej pozostaje bez precedensu.

\section{Kontekst ukraiński}

Zarówno w rozmowach z aktywistkami, jak i postronnymi obserwatorami ich akcji na temat problemu reprezentacji i tożsamości Femenu przewijały się niemal wymiennie określenia „ruch" i „organizacja”. Czym zatem jest Femen? Które określenie i łączący się z nim ciężar znaczeniowy bardziej do niego pasuje? Biorąc pod uwagę wciąż nieokreślony status prawny Femenu w jego rodzinnym kraju oraz ogólną sytuację sektora pozarządowego w Ukrainie,

\footnotetext{
${ }^{4}$ Więcej o etnograficznych metodach badawczych w: Hammersley \& Atkinson, 2000.
} 
pytanie to wydaje się nie pozbawione sensu. Wychodząc od teorii, ruch społeczny jest zbiorowym dążeniem pewnej grupy ludzi, w której wyodrębnia się liderów, rzeczników i aktywistów oraz zwolenników i sympatyków (Paleczny, 2010, s. 19). Poza hasłem walki o prawa kobiet trudno jednak wyróżnić zdecydowaną ideologiczną orientację Femenu - aktywistki przytaczają swoje inspiracje marksizmem, jednak samo przesłanie ruchu trudno uznać za jednoznacznie zorientowane politycznie; bliższe naturze Femenu wydaje się używane przez prasę, w założeniu krytyczne hasło „Femen przeciwko wszystkim”. Pod tym względem trudnym zadaniem jest zdefiniowanie Femenu pod kątem charakterystyki dążeń jego członków (według klasyfikacji Palecznego, ss. 20-21), ponieważ mogą to być zarówno postulaty feministyczne, religijne (czy też antyreligijne), anarchistyczne czy obyczajowe, a jednocześnie żadne z nich nie wyczerpują listy celów, jakie wciąż na nowo definiują aktywistki - zarówno ukraińskie liderki, jak i działaczki z innych krajów (z tzw. „oddziałów lokalnych” rozsianych po Europie i poza nią). Analizując jednak treść postulatów publikowanych przez Femen na jego stronach internetowych, portalach społecznościowych oraz w oficjalnych i nieoficjalnych wypowiedziach, można dojść do wniosku, że reprezentuje on przede wszystkim ruch radykalny, że sama "radykalność" - deklaratywna czy faktyczna - stanowi o istocie ich ram pojęciowych. Sam radykalizm, czyli dążenie do obalenia zastanego systemu społecznego (opartego obecnie na patriarchacie w jego trzech głównych przejawach: dyktaturze, kościele i sex industry ) i zastąpienia go nowym, nie stanowiłby znaczącego wyróżnika na szeroko pojętej ukraińskiej scenie politycznej, zwłaszcza kiedy założymy, że każdy przejaw działania zbiorowego bierze się z niezgody na otaczającą rzeczywistość - zarówno ten dążący do modernizacji, jak i ten sprzeciwiający się jej; jednak to pełne zaangażowanie wykorzystujące przekaz medialny, nutę kontrowersji i skandalu czyni z Femenu najprężniejszy ruch w regionie.

Ukraina szczyci się sporą liczbą organizacji pozarządowych oraz dość wysokim stopniem zaufania ukraińskiego społeczeństwa do tego rodzaju przedsięwzięć, jak wykazują badania ankietowe (Kaźmierkiewicz, 2012, ss. 213-215). Jeśli z takiej ilościowej próby można wyciągać pewne wnioski natury ogólnej, to raczej ryzykując przy tym tezę, że dzieje się tak pomimo faktu - a nie dlatego - że gros organizacji pozarządowych to nie są twory samodzielne, lecz uzależnione od politycznych wpływów: wiele z nich jest zakładana lub finansowana przez deputowanych różnych szczebli, ludzi związanych z polityką czy biznesem, który w powszechnym przekonaniu zawsze jest z polityką połączony. W rozmowach o aktywności obywatelskiej czy kulturze protestu z osobami niezwiązanymi bezpośrednio z Femenem, ale śledzącymi (z różnym natężeniem) działania kijowskich aktywistek, często padały przykłady opłacanych demonstrantów, wynajmowanych przez rozmaite partie 
lub pojedynczych polityków, by stwarzali wrażenie masowego poparcia. Taki stan rzeczy nazywany jest czasem „społeczeństwem quasi-obywatelskim”, to znaczy społeczeństwem opartym o „instytucje, które w odróżnieniu od organizacji obywatelskich typu grassroots są aktywnie wykorzystywane i wspierane przez instytucje związane z władzą dla uzyskania akceptacji, czyli pewnego rodzaju formalnej legitymizacji, najróżniejszych inicjatyw władz, co jest odtwarzaniem praktyk radzieckiego formalizmu we współczesnych realiach ukraińskich" (Tyszczenko \& Bakalczuk, 2012, s. 235). Pomimo tych ambiwalentnych odczuć, sytuacja sektora NGO w Ukrainie i tak uważana jest za lepszą niż w latach 2005-2010, kiedy to zanotowano wyraźny spadek aktywności (Kaźmierkiewicz, 2012, ss. 218-219). Co ciekawe, według wielu ekspertów stało się tak z powodu euforii po zwycięstwie Pomarańczowej Rewolucji, będącej triumfem licznych organizacji obywatelskich, po której nastąpiła swoista demobilizacja obywateli oparta na przekonaniu, że po zwycięstwie obozu reform zdobycze demokracji są bezpieczne i nie wymagają masowego zaangażowania (Kaźmierkiewicz, 2012, ss. 218-220, zob. też: Kohut, 2012). Wynika z tego, że na przekór ogólnej tendencji Femen powstał w czasie nikłego zainteresowania działalnością społeczną, w okresie pewnego zastoju w działaniach obywatelskich. Jednak nie przeszkodziło mu to w ciągu paru lat rozwinąć aktywności i wyjść poza granice kraju, co odbyło się nie dzięki wsparciu sympatyków z Ukrainy, a raczej pomimo jego braku, jako że wraz z rozpoznawalnością nie przyszło masowe poparcie. Gdzie zatem plasuje się Femen na ukraińskiej mapie politycznej ruchów obywatelskich, organizacji pozarządowych typu grassroots?

Na swojej oficjalnej stronie na portalu Facebook Femen opisuje siebie, swoje cele i postulaty w trzech różnych językach: angielskim, rosyjskim i ukraińskim, w każdym podając nieco inną definicję tego, czym tak właściwie jest Femen ${ }^{5}$. Po angielsku określał się on tam jako Ukrainian protest group („ukraińska grupa protestu”), po rosyjsku украинская феминистская организация („ukraińska organizacja feministyczna”), natomiast po ukraińsku jako українська громадська організація („ukraińska organizacja obywatelska”). $\mathrm{Na}$ oficjalnej stronie internetowej http://femen.org widnieje natomiast opis, który, powielając już podane definicje, dodaje także nowe. Brzmi on: „Femen - to ogólnoświatowy ruch kobiecy / Femen - to nazwa słynnej skandalizującej organizacji topless-aktywistek, za pomocą własnych piersi broniących płciowego i obywatelskiego równouprawnienia na całym świecie." ${ }^{6}$ Co to właściwie oznacza?

\footnotetext{
${ }^{5}$ Opis zaczerpnęłam z nieistniejącego już profilu www.facebook.com/Femen.UA, który został przez administratorów portalu usunięty z powodu obrazów ukazujących nagość i „promujących pornografię”; na jego miejsce aktywistki utworzyły nowy profil pod adresem www.facebook.com/Femen International, o czym piszę dalej.

${ }^{6}$ http://femen.org/about („FEMEN", b.d.-b)
} 
Rosyjskie słowo движение jest tłumaczone jako „ruch" і posiada niemal dosłownie takie samo znaczenie jak w języku polskim - jest to ruch społeczny, obywatelski, także w pojęciu filozoficznym, ale również fizycznym czy biologicznym (Wawrzyńczyk, 2008, s. 76). $\mathrm{Na}$ innej informacyjnej stronie internetowej http://femen.info z kolei znaleźć można opis жіночий рух Femen - українська громадська організація ${ }^{7}$ („kobiecy ruch Femen - ukraińska organizacja obywatelska"). Mówiąc o swojej działalności aktywistki używały przede wszystkim rosyjskiego określenia движение, czyli „ruch", ale czasem mówiły o sobie także jako „organizacji” - głównie w kontekście prawnym, spraw związanych z próbą o urzędową rejestrację. Sam Femen określa więc siebie różnorako i dość niespójnie - jako organizację kobiecą, grupę protestu, ruch społeczny lub organizację feministyczną. Chociaż zarówno określenia "ruch" jak i „organizacja” są moim zdaniem w pewnym sensie adekwatne do opisu zjawiska jakim jest Femen, to jednak przychylam się do określenia "ruch" jako lepiej oddającego charakter jego działalności. Jednocześnie uważam, że żadne z tych pojęć nie oddaje w pełni wszystkich wymiarów istnienia i funkcjonowania Femenu, a przede wszystkim nie oddaje zmian, jakie zaszły w procesie organizacyjnym i formalnym w ciągu ostatnich dwóch lat, kiedy prowadziłam swoje badania. Od początku grupa aktywistek działająca w Kijowie nie była oficjalnie zarejestrowana jako podmiot prawny, działała (i nadal działa) na zasadzie luźnego związku obywatelskiego (объединение граждан), który jako nieposiadający statusu prawnego nie musi informować władz o podejmowanych działaniach; stało się tak przede wszystkim dlatego, że władze odmówiły zarejestrowania Femenu jako organizacji. Chociaż prawo do tworzenia i członkostwa w stowarzyszeniach stanowi „niezbywalne prawo człowieka, gwarantowane przez Powszechną Deklarację Praw Człowieka oraz Konstytucję Ukrainy i jej prawa" według preambuły ustawy uchwalonej przez Radę Najwyższą w 1992 roku „O stowarzyszeniach obywateli” (za: Kaźmierkiewicz, 2012, s. 216), nowelizowanej według zaleceń Europejskiego Trybunału Praw Człowieka w 2013 roku, to jednak w artykule 4 ustawa przewiduje odmowę zarejestrowania stowarzyszenia, które działałoby w celu „eliminacji niezależności Ukrainy, naruszenia porządku konstytucyjnego (...), przemocy, podżegania do nienawiści na tle etnicznym, rasowym i religijnym, zagrożenia praw człowieka i zdrowia ludności". Prawdopodobnie tym uzasadniono odmowę zarejestrowania Femenu jako organizacji. Ostatecznie aktywistkom udało się zrejestrować Femen jako międzynarodową organizację jesienią 2012 roku we Francji, po ucieczce Inny Szewczenko do Paryża. Chociaż oficjalnie zarejestrowany, Femen przejawia jednak raczej

\footnotetext{
${ }^{7}$ http://femen.info/pro-projekt/ („FEMEN”, b.d.-a)

8 „Закон України про громадські об'єднання” dostępny na stronie Rady Najwyższej: http://zakon2.rada.gov.ua/laws/ show/4572-vi („Закон України про громадські об'єднання”, b.d.).
} 
tendencje do identyfikowania się jako ruch - społeczny, obywatelski, protestacyjny - niż do działania w ramach ograniczonej ustawowo organizacji.

\section{Ruch Femen: nowy, globalny, lokalny}

Aktywność Femenu jest bez wątpienia działaniem zbiorowym, jednak nie w sensie bycia charakterystycznym "dla zachowań i działań masowych, wielkich zbiorowości” (Paleczny, 2010, s. 12). Jak już wspomniałam, działania Femenu trudno uznać za "masowe" pod względem ilości zaangażowanych w nie osób, ich siła rażenia leży raczej w masowości przekazu, na który nastawiają się aktywistki, niż na pozyskaniu tłumów zwolenników. Femen jest przy tym ruchem dość otwartym (nie ma wyśrubowanych wymogów członkostwa), lecz jednocześnie ekskluzywnym - przyjęcie w poczet aktywistek (bądź aktywistów - mężczyźni również wspierają Femen na jego zapleczu) musi poprzedzić wzajemne zaufanie, zbudowanie pewnej więzi. To również odróżnia relacje w obrębie Femenu od tych obecnych w teorii klasycznych ruchów społecznych, która opisuje interakcje w ruchu społecznym jako „przelotne, nieformalne, komunikacyjne, trwałe” (Paleczny, 2010, s. 13) i lokuje go raczej po stronie nowych ruchów społecznych cechujących społeczeństwa ponowoczesne (por. della Porta \& Diani, 2010; Paleczny, 2010).

Takie ruchy - nowe ruchy społeczne - funkcjonując w innej, postindustrialnej rzeczywistości nie skupiają się już na aspekcie materialnym, lecz ideowym i kulturowym - na przykład właśnie na walce o prawa kobiet. Sama teoria nowych ruchów społecznych stworzona została co prawda na potrzeby opisania przemian zachodzących w społeczeństwach zachodnich (ekonomiach postindustrialnych) od mniej więcej lat 60. (zob. Pichardo, 1997, ss. 411-430), jednak uważam, że od czasów gwałtownych przemian w tzw. krajach postsowieckich w latach 90. podobną analizę można zastosować do realiów ukraińskich - zwłaszcza gdy weźmie się pod uwagę, przywołując słowa samych aktywistek Femenu, że na Ukrainie „nigdy nie było seksualnej rewolucji” (zob. „Mrijemo wywesty na wulicu tysjaczi ogolonych żinok", 2012, s. 49). Zjawisko "urynkowienia seksu" w latach 90. w Ukrainie mogło więc pojawić się wraz z zaistnieniem tzw. "marketplace of ideas”, czyli możliwości swobodnej wypowiedzi, przepływu teorii, idei i ruchów ${ }^{9}$ - a w efekcie umożliwiło powstanie ruchu takiego jak Femen. Ponadto Femen w swoich założeniach wpisuje się w cele przyświecające nowym ruchom społecznym, które „stanowią próbę przeciwstawienia się wdzieraniu się

\footnotetext{
${ }^{9}$ Więcej na temat idei „market place of ideas": http://uscivilliberties.org/themes/4099-marketplace-of-ideas-theory.html („Marketplace of Ideas Theory", b.d.)
} 
państwa i rynku w sferę życia społecznego. Kładą one nacisk na prawo jednostek do definiowania własnej tożsamości oraz sterowania życiem prywatnym i emocjonalnym w obliczu wszechobecnego, wszechogarniającego, manipulacyjnego systemu" (della Porta \& Diani, 2009, ss. 10-11). Poza tym „nie ograniczają się do poszukiwania korzyści materialnych, ale starają się też zmienić powszechne definicje polityki i społeczeństwa" (della Porta \& Diani, 2009, s. 11) oraz "definiują się przez silny ładunek kulturowy, kontestują dość bezpośrednio orientacje kulturowe społeczeństw, w których żyją" (Wieviorka, 2011, s. 81) - co jak najbardziej zgadza się z postulatami aktywistek Femenu mówiącymi o obaleniu patriarchalnych fundamentów kultury. W tym duchu można by pokusić się o nazwanie Femenu ruchem protestu w duchu zorganizowanych protestów studenckich czy robotniczych w Europie Zachodniej w latach 60. (więcej: della Porta \& Diani, 2009), jako że to aktywny akt protestu stanowi właśnie rdzeń ich ideologii. Sądzę jednak, że zjawisko jakim jest Femen zawiera w sobie znacznie więcej niż tylko retorykę protestu, by mógł być ekskluzywnie do tego pojęcia przypisany. Przede wszystkim aktywistki pokusiły się o coś więcej, to jest o stworzenie własnych ram interpretacyjnych (jak same mówią - „ideologii") organizujących ruch - sekstremizmu - i wykraczających, jak twierdzą, poza przyjętą definicję „feminizmu”: ruchu wypalonego i bezsilnego.

Jednak podział na „stare" i „nowe” ruchy społeczne nie jest ani do końca jasny, ani oczywisty - szczególnie widać to w przytoczonym przypadku. Cechą nowych ruchów społecznych jest z zasady zerwanie z tradycją, innowacyjność, nowość, postępowość, odcięcie się od zastanego porządku - pod tym względem Femen zalicza się bez wątpienia do nowych ruchów społecznych. Jednak w tym samym czasie ruchy odwołujące się - znów tak jak Femen - do ideałów sprawiedliwości społecznej, bazują na ideach wypracowanych wcześniej przez "stare" ruchy - jak socjalizm czy komunizm (Paleczny, 2010, ss. 23-24), a nawet feminizm. Jak wskazuje na przykład Paleczny (2010, s. 24), wiele współczesnych ruchów kontestacyjnych, ruchów protestu przekształca się w ruchy populistyczne, odwołujące się do utopijnej wizji społeczeństwa bezklasowego (włączając w to klasę seksualną), otwarcie zahaczając o wątki anarchistyczne, co nie ominęło również Femenu. Jeśli więc patrzeć na populizm jako na "ludową" wersję nowych ruchów społecznych, to jest on swoistym pomostem łączącym "stare" z "nowym” (Paleczny, 2010, s. 24). Biorąc jednocześnie pod uwagę kontekst historyczny czasu powstania Femenu, jego inspiracji marksizmem oraz otwartego populizmu, widać wyraźnie, że podział stworzony między starymi a nowymi ruchami społecznymi jest umowny, a teoria nowych ruchów społecznych nie do końca adekwatna w stosunku do realiów Ukrainy przełomu XX i XXI wieku. Jeśli jednak analizować 
Femen w przyjętych ramach "nowych ruchów społecznych", to widać wyraźnie, że niewielkie poparcie, jakim cieszy się wśród ogółu Ukraińców, nie jest wynikiem jego niepowodzenia w realizacji swoich celów - cechą nowych ruchów społecznych nie jest bowiem masowość, lecz specyficzna charakterystyka członkostwa, która je wyróżnia, a przy tym sympatia (czy też po prostu zainteresowanie) środków masowej komunikacji (Paleczny, 2010, ss. 26-27). Zgadza się to z tym, co mówią same femenki, a mianowicie że są zbyt radykalne, by przyciągnąć do siebie rzeszę kobiet, zwłaszcza z tak tradycyjnego kraju, jakim jest Ukraina. Ich początkowa (i wciąż miejscami widoczna) fascynacja marksizmem oraz ideą permanentnej rewolucji dobrze pokazuje drogę, którą przeszły; od początkowego planu rejestracji i niewykluczenia wejścia do polityki (w 2010 r. Anna Hucoł zadeklarowała, że Femen chciałby wystartować kiedyś w wyborach) po totalną kontestację systemu, zarówno politycznego, jak i społecznego. Kontestując system, femenki nie dążą do jego całkowitego zburzenia, obalenia, lecz do jego gruntownej zmiany.

\section{Wróg: próba definicji}

Wracając do poruszonej kwestii wroga społecznego, trzeba jeszcze raz zaznaczyć, że w tym przypadku ów wróg jest dość szeroko zarysowanym przeciwnikiem określanym jako „patriarchat", z czym wiąże się kwestia - również typowa dla nowych ruchów społecznych - pewnej trudności w ostatecznej i szczegółowej identyfikacji tego społecznego przeciwnika; przykładem mogą być choćby antynuklearni aktywiści we Francji, którzy długo nie mogli zgodzić się między sobą co do tego, że ich realnym wrogiem są technokratyczne układy próbujące narzucić społeczeństwu swój program elektronuklearny (Paleczny, 2010, s. 80). Aktywistkom Femenu dopiero po paru latach udało się sprecyzować podstawowy cel walki i poprzez manifesty zamieszczane na swoich stronach internetowych oraz szeroko udzielane wywiady prasowe przekazać opinii publicznej, jakich konkretnych aktorów uważają za swojego głównego wroga (tzn. przemysł seksualny, dyktaturę i Kościół). Wcześniej ich akcje skierowane były przeciw tak różnym zjawiskom, jak polityka gazowa Gazpromu czy wciąż żywy sowiecki zwyczaj zakręcania latem ciepłej wody w akademikach na co najmniej dwa tygodnie. Takie akcje były na tyle rozbieżne oraz dalekie od przyjętej wizji tego, czym jest patriarchat i walka z nim, że nie były przez większość widzów interpretowane jako spójny z deklarowanymi założeniami ruchu. Nawet po skonkretyzowaniu i wypunktowaniu wroga, wciąż określenie tego, co jest, a co nie jest naruszaniem praw kobiet czy seksizmem, sprawia pewne trudności i nie jest jednoznacznie rozumiane przez odbiorców akcji Femenu - czyli 
de facto przez miliony ludzi czytających doniesienia prasowe i oglądających przekazy medialne. Ta płynność i rozmycie granic, typowa dla myśli postmodernistycznej (czy nawet post-postmodernistycznej) ogłoszającej koniec „wielkich narracji” i czas globalizacji, sprawiła, że pod wieloma względami Femen - w czasie całego swojego rozwoju, zaczynając od akcji o zasięgu ukraińskim do ruchu europejskiego i światowego - stał się w pewnym sensie tym, co można nazwać „ruchem globalnym”. To te właśnie ruchy "sprawiają wrażenie mgławicy sprzeciwiającej się rozproszonemu przeciwnikowi, bezosobowemu, bardzo źle zidentyfikowanemu, mgławicy jak najdalszej od robotniczego ruchu sprzed wieku, który był w stanie podważyć pozycję właścicieli w sposób relatywnie precyzyjny" (Wieviorka, 2011, s. 87). W ich przypadku ramy państwa narodowego są już znacznie osłabione i nie stanowią przeszkody w podążaniu za przyświecającymi im celami, ponieważ przestrzenie ich życia społecznego, politycznego i kulturalnego są coraz mniej zintegrowane; Femen, jeszcze będąc ruchem zakotwiczonym w Kijowie, stopniowo, ale konsekwentnie rozszerzał zasięg swoich protestów na resztę Europy, idąc tam, gdzie głośno było o naruszaniu praw kobiet (np. protesty w Rzymie przeciw znanemu z seksizmu i oskarżanemu o molestowanie premierowi Włoch Silvio Berlusconiemu czy oskarżonemu o gwałt na pokojówce Dominique'owi Strauss-Kahnowi w Paryżu), nie zważając na polityczne granice. Myślę, że w dużej mierze oddaje to obecne nastawienie działaczek Femenu, które podobnie jak aktywiści ruchów globalnych, jak opisuje to Wieviorka, „nie myślą wyłącznie w terminach państw i narodów i nie są wrogie powoływaniu się na prawo do ingerencji, żeby wykroczyć poza najbardziej brutalne implikacje klasycznego pojęcia suwerenności państw" (2011, ss. 85-87).

\section{Popfeminizm}

Niezwykle istotnym elementem tożsamości Femenu jako ruchu jest bez wątpienia samookreślanie się aktywistek jako przedstawicielek „popfeminizmu”. Co to właściwie oznacza? Femenki określają swoją grupę mianem radykalnego ruchu kobiecego, a "radykalny”, jak same przyznają, w tym wypadku znaczy przede wszystkim skandalizujący. „Ogólnie uważamy, że jeśli na dzień dzisiejszy trzeba działać radykalnie, to radykalnie znaczy topless", twierdzi Anna Hucoł (za: Majerczyk \& Płachotnik, 2011). Z jednej strony nagie ciała mają być ich manifestem - znakiem wyzwolenia z pęt patriarchatu, który przez wieki decydował o kobiecej seksualności, mają symbolizować nadchodzącą rewolucję obyczajową i polityczną. $Z$ drugiej mają one przyciągać uwagę; ich pokazywanie nastawione jest także na czysto medialny efekt skandalu, przełamania kulturowego zakazu obnażania kobiecego biustu. 
Aktywistki głoszą, że choć fizycznie należy on do kobiet, to wciąż jednak znajduje się pod symboliczną władzą mężczyzn. Pokazywanie go publicznie jest więc samo w sobie aktem kontestacji wobec obowiązującego porządku, ciało samo w sobie jest przekazem. Wbrew pozorom w teoriach ruchów społecznych i zachowań zbiorowych bardzo mało miejsca poświęcano dotąd ciału jako takiemu; ciału w wymiarze bardziej fenomenologicznym, będącym nie kartezjańskim przeciwieństwem umysłu, lecz ciałem własnym - podmiotem percepcji, byciem i poznaniem jednocześnie (Merleau-Ponty, 2001). Jest ono „pierwszym przyzwyczajeniem, które warunkuje wszystkie inne i pozwala je zrozumieć" (Merleau-Ponty, 2001, s. 110). W tym kontekście ciało wydaje się kluczowe do zrozumienia strategii oporu przyjętej przez Femen. W dużej mierze teorie ruchów społecznych bardziej skupiają się na takich czynnikach wpływających na wymiar społecznego aktywizmu, jak motywacja czy poznanie, niż na emocjach i ciele (Sasson-Levy \& Rapoport, 2003, s. 382). Uważam, że zrozumienie znaczenia ciała, jego "repozycji” w stosunku do pierwotnego kulturowego znaczenia oraz roli w spektaklach protestu jest $w$ tym przypadku kluczowe dla zrozumienia idei ruchu oraz jego związku z genderowym kontekstem rzeczywistości społecznej i politycznej zarówno Ukrainy, jak i państw zachodnich.

Ciało jest przez Femen traktowane jako broń - broń ekskluzywnie kobieca, mająca demonstrować wolność od narzucanych odgórnie męskich zasad, według których kobiece ciało przynależy do sfery prywatnej, nie zaś publicznej, i to zarówno w wymiarze fizycznym, jak i politycznym (Femen ma na swoim koncie protest z 2010 roku przeciwko premierowi Mykole Azarowowi, który stwierdził wówczas, że polityka i wprowadzanie reform nie jest zajęciem dla kobiet, ponieważ nie umieją one mówić „nie”). Szczególnie adekwatne wydaje się to w kontekście Ukrainy, kraju o wciąż - mimo napływających zachodnich liberalnych trendów - konserwatywnej obyczajowości, podtrzymywanej przez oficjalną politykę państwa. To, co zdaniem Femenu jest powodem odstawania Ukrainy od reszty Europy, to jest jej historyczne dziedzictwo z czasów ZSRR oraz związany z tym wspominany już brak doświadczenia rewolucji seksualnej. Ów brak seksualnej rewolucji, która zmieniłaby świadomość Ukraińców na wzór zachodni, jest często przywoływanym przez aktywistki powodem braku masowego poparcia dla nich w ich ojczyźnie oraz braku gotowości Ukraińców do zaakceptowania stylu walki, jakim jest sekstremizm. W tej formie ideologicznego protestu nagie ciało służy do alternatywnego „odgrywania” utartego, wciąż silnie zakorzenionego w społecznej wyobraźni wizerunku kobiety, negowania obowiązujących kodów kulturowych, w czym tkwi jego siła (Swidler, 1995, za: Sasson-Levy \& Rapoport, 2003, s. 395). 
Używając nagiego ciała w walce przeciw patriarchatowi, Femen stawia wyzwanie klasycznie postrzeganemu feminizmowi oraz roli kobiety w społeczeństwie.

Trzeba w tym miejscu wspomnieć, że samo słowo „feminizm", kojarzone z feminizmem w wydaniu zachodnim, niesie dla większości Ukraińców raczej pejoratywne skojarzenia (zobacz więcej: Płachotnik, 2012; Kiś, 2012). Kiedy Europę przestała dzielić żelazna kurtyna, do Ukrainy zaczęły szerszym strumieniem napływać zachodnie idee feministyczne, spotkały się one jednak z nikłym odzewem wśród ukraińskich kobiet, a myśl feministyczna pozostała zamknięta w środowiskach akademickich (Płachotnik, 2012). Tak też postrzegają feminizm działaczki Femenu, odżegnując się od tej, ich zdaniem, nieefektywnej formy sprzeciwu. Jak mówiła w prasie Inna: „klasyczny feminizm jest jak stara, chora kobieta, która już nie może nic zdziałać. Utknęła w świecie konferencji i książek. My mamy te same idee co klasyczne feministki, ale różni nas forma walki. Walczymy w sposób, który na powrót przyciągnie młode kobiet do ideologii"10. Femenki prowadzą swoją walkę nie zaprzeczając więc powszechnemu wyobrażeniu o młodej ukraińskiej kobiecie jako istocie na wskroś seksualnej, atrakcyjnej, lubiącej ładnie się ubrać i umalować. Wręcz przeciwnie, wykorzystują ten wizerunek, kontrując stereotypowe wyobrażenie o płytkiej, biernej i interesownej dziewczynie, której jedyną ambicją jest znalezienie bogatego męża (stereotypu bardzo rozpowszechnionego w Ukrainie, z którym wiele razy sama się zetknęłam) agresywnym wydźwiękiem swoich akcji oraz ich wyraźnym aspektem politycznym. Postrzegam Femen właśnie jako ruch oddolny zajmujący się performatywnymi i cielesnymi politycznymi manifestacjami (w ten sposób opisuje je Zychowicz, 2011). Ich stosunek do 'klasycznego feminizmu' oraz do wykorzystywania kobiecego ciała podczas protestów zdecydowanie odróżnia je nie tylko od ukraińskich, ale i większości europejskich grup feministycznych (zob. Zychowicz, 2011, ss. 217-220).

W tym kontekście warto jeszcze raz podkreślić, że od początku swojej działalności femenki skupiły się nie na walce $z$ imagem młodych Ukrainek, lecz raczej ze społecznym odbiorem ich poczucia estetyki - z faktem, że często brane są przez zachodnich mężczyzn (oraz przez władze ich własnego kraju, często odmawiających im wiz) za prostytutki tylko ze względu na to, jak wyglądają i jak się ubierają. Walka była więc wymierzona w „oko patrzącego", a nie w same młode dziewczyny i ich poczucie estetyki i stylu. Co ważne, ów styl jest postrzegany jako "swój” przez same aktywistki, które nie zamierzały się od niego odżegnywać, ani go zmieniać. Określały tę stylistykę mianem „stylu ukraińskich dziewcząt”,

\footnotetext{
${ }^{10}$ Cytat za: Femen's topless warriors start boot camp for global feminism, "The Guardian",

http://www.guardian.co.uk/world/2012/sep/22/femen-topless-warriors-global-feminism („Femen's topless warriors start boot camp for global feminism", b.d.)
} 
którego nie mają zamiaru się wyrzekać, a który nie stoi w sprzeczności z wyznawanymi przez nie ideałami równości i praw kobiet. Działaczki uważają tę estetykę za coś naturalnego, kobiecego - ów styl prezentowania się jest częścią ich ciała własnego, doświadczeniem określającym to, kim są; nierozerwalnym byciem i poznaniem, warunkującym sposób odbioru bodźców ze świata. Doświadczenie jednostkowe każdej z nich znalazło swoje odzwierciedlenie w dynamice, w wyniku której podzielane odczucia na poziomie mikro doprowadziły do zjawiska na poziomie makro, jakim jest właśnie działalność Femenu (della Porta \& Diani, 2009, s. 13). Jednak paradoksalnie ten sam styl, który wyprowadził je w stronę działania zbiorowego i który czyni je wiarygodnymi w roli „młodych ukraińskich dziewcząt", dyskredytuje je jednocześnie w roli działaczek i aktywnych uczestniczek życia społecznego, i to nie tylko w Ukrainie. Seksualna atrakcyjność ciał stała się obosieczną bronią - przyciąga uwagę do poruszanego problemu, ale nierzadko zostaje przesłonięta kulturową kliszą i postrzegana przez pryzmat utartych schematów. Ideą aktywistek jest jednak stworzenie nowego feminizmu - w odróżnieniu od zdyskredytowanego "klasycznego feminizmu" - który będzie prężnie się rozwijał i działał. Pewien etap tego planu już udało im się osiągnąć - na swojej stronie internetowej Femen z dumą obwieścił, że według najpopularniejszej wyszukiwarki internetowej Google i narzędzia Google Trends mierzącego popularność określonych wyszukiwań liczba zapytań dla hasła „femen" przekroczyła te dla haseł "feminism" czy "feminist" ${ }^{\prime 11}$. Stąd też prawdopodobnie tak entuzjastyczne przyjęcie przez femenki określenia pop-feminizm, jakim ochrzciły ich działania media, a które szybko weszło do ich słownika. W pop-feminizmie znajdzie się miejsce zarówno dla hiperseksualnej estetyki królującej na kijowskich (i nie tylko) ulicach, jak i dla chwytliwych, często obrazoburczych czy populistycznych haseł poruszających tematy polityczne i obyczajowe. Ponieważ jednym z głównych celów Femenu jest zmiana postrzegania samego feminizmu, oderwania go od skojarzeń z surową akademickością i biernością, świadomie zdecydowały się więc na promocję ideologii w wersji pop: dostępnej dla wszystkich, atrakcyjnej dla młodych kobiet, takiej, która może przyciągnąć do ruchu młodzież, która będzie przystawać do nowych czasów. Wyczuwając wymagania młodych ludzi, femenki kierują się bardziej własnym wyczuciem niż naukowymi czy środowiskowymi trendami. Często w swoich wypowiedziach idą pod prąd obecnie „obowiązującej” wykładni feministycznej, bywają na przykład otwarcie nastawione na konflikt z religią, z którą „feminizm nie może koegzystować" czy na esencjalistyczne określanie płci, od czego odżegnywała się już druga feministyczna fala na Zachodzie.

${ }^{11}$ za: http://femen.info/femen-took-over-femenism/ („FEMEN took over feminism”, b.d.) 


\section{Na Zachód}

Choć ukształtowany w Ukrainie, Femen wydaje się obecnie rozwijać skrzydła przede wszystkim w akcjach przeprowadzanych poza Ukrainą, przyciągając nimi znacznie więcej nowych aktywistek, gapiów oraz uwagi mediów. Te wyrazy popularności i zainteresowania, choć nie tak liczne jak w przypadku niektórych innych ruchów (np. Occupy Wall Street czy Oburzonych), są i tak duże w porównaniu ze znikomym poparciem, jakim cieszą się w rodzinnym kraju, w którym po przeniesieniu się trzech głównych działaczek do Paryża i Berlina dzieje się z inicjatywy ruchu już bardzo niewiele (zwłaszcza w porównaniu do wcześniejszych lat 2010-2012). Femen zdecydowanie zrobił w swojej działalności ruch w kierunku Zachodu, tym bardziej zachodnia definicja dotycząca formy ich aktywności jest tu moim zdaniem zdecydowanie na miejscu. Wielu młodych ludzi z Kijowa w czasie wywiadów i nieformalnych rozmów nie definiowało nawet Femenu jako „ruchu społecznego" ani przejawu jakiejkolwiek działalności obywatelskiej - najczęściej wydawało im się to zbyt poważną nazwą na takie "niepoważne" akcje jak nagie protesty. Mimo tego według innej definicji nowych (młodzieżowych) ruchów społecznych, opartej na doświadczeniach i historii ruchów protestu $\mathrm{z}$ francuskich, amerykańskich i japońskich uniwersytetów, „obronę <<ja>> można połączyć z walką i wizją nowego społeczeństwa. Wtedy powstaje ruch społeczny. Nie musi być koniecznie zintegrowany, świadomy i zorganizowany, ale może stać się czynnikiem wywołującym konflikty i przemiany społeczne. Taki ruch zdoła zaistnieć tylko pod warunkiem, że wykroczy poza ograniczenia charakterystyczne dla grupy, jaką jest młodzież. Powstanie jedynie wtedy, gdy kulturowe wycofanie i społeczny bunt połączą się i zniosą same siebie w tym związku. Związek może opierać się na jednym albo drugim biegunie" (Touraine, 2010, s. 253). W tym wypadku niespójność i słaba organizacja, częsty zarzut wobec Femenu, nie muszą dyskwalifikować go jako ruchu społecznego i poważnego politycznego aktora, zwłaszcza na okrzepłym w tradycjach ruchów protestu Zachodzie. Aktorom społecznym zaangażowanym w działania zbiorowe niezbędna jest elastyczność i umiejętność dostosowywania się do różnych okoliczności i różnych odbiorców, dostosowania swoich działań tak, aby zmobilizować jak największą część swojej grupy docelowej. Można nawet powiedzieć, za della Portą i Dianim, że „ważnym warunkiem sukcesu ruchów społecznych jest umiejętność takiego przeformułowania swoich wartości i motywów, by jak najlepiej dostosować je do postaw odłamu opinii publicznej, do którego kieruje się działania mobilizujące”, a także, że „konieczność elastyczności i adaptacji powoduje, że silna identyfikacja z określonymi normami i wartościami może być przeszkodą w swobodnym działaniu" (della Porta \& Diani, 2009, s. 81). Pod tym względem Femen przy całej swojej 
niekonsekwencji - która przy tak dynamicznie rozwijającym się ruchu jest nieunikniona - działa jak najbardziej zgodnie z logiką ruchu, który ma ambicje przejść do sfery globalnej oraz aktywizować coraz więcej ludzi z różnych kręgów i środowisk.

Problem pojawia się raczej przy punkcie mówiącym o wykroczeniu poza ograniczenia charakterystyczne dla grupy młodzieżowej. Nie chodzi tu jednak, jak w przypadku młodzieżowych grup protestu z francuskich uniwersytetów, o wyjście poza postulaty zawężone do bardzo specyficznej grupy społecznej walczącej o przywileje w zdefiniowanej dziedzinie edukacji i rynku pracy - w istocie Femen definiuje zarówno grupę docelową swoich protestów, jak i głównego wroga, bardzo szeroko. Bardziej niż o ograniczenia strukturalne chodzi o problemy formalne i wizerunkowe - większość aktywistek to młode, atrakcyjne, jasnowłose dziewczyny ucieleśniające wyobrażenia o urodzie ukraińskich dziewcząt. Ich półnagie zdjęcia zamieszczane w Internecie (czy to na ich oficjalnej stronie, na Facebooku czy przy artykułach prasowych) bardzo często ściągają komentarze dotyczące ich wyglądu i urody. Oprócz podejrzliwości, którą budzi ich wizerunek prezentowany w mediach, zawęża to także potencjalny krąg ich stronniczek i naśladowczyń nie dysponujących tak pięknymi ciałami, które mogłyby zmienić $w$ tak pojmowaną, zasadzającą się na atrakcyjności, broń (zgodnie z jednym z haseł Femenu i tytułem filmu dokumentalnego dwóch francuskich reżyserek Caroline Fourest i Nadii Elfany „My Body, My Weapon” opartego na historii pierwszych pięciu miesięcy Inny Szewczenko w Paryżu). Z drugiej strony kulturowe wycofanie oraz społeczny bunt łączą się w przypadku Femenu nadspodziewanie dobrze. Zakładając, że z jednej strony „odwołanie do wymiaru wspólnotowego staje się obroną środowiska i opozycją wewnątrz władz wielkich aparatów instytucjonalnych", natomiast z drugiej „mamy do czynienia ze społecznym buntem skierowanym przeciw najbardziej ogólnym politycznym decyzjom, zwłaszcza przeciw imperializmowi, buntem, który na niższym poziomie staje się krytyką konkretnych instytucji i kulturową mobilizacją" (della Porta \& Diani, 2009, s. 81), zaryzykowałabym stwierdzenie, że Femen opiera swoje działania głównie na tym drugim filarze - to znaczy krytyce patriarchalnych zasad rządzących społeczeństwem i zjawisk takich jak dyskryminacja i zniewolenie kobiet.

Trudno przy tym określić na ile ruch - dla utrzymania wiarygodności - powinien znajdować się w głównym nurcie, być mainstreamowy, a na ile może (czy powinien) być alternatywny, niszowy. Dobrym wyznacznikiem tego, czym jest - lub czym powinien być - ruch społeczny, wydaje się być raczej poczucie przynależności i podzielanej z innymi uczestnikami tożsamości; to właśnie pomiędzy tożsamością jednostki a działaniem zbiorowym zachodzi wtedy szczególna relacja, którą odnieść można przede wszystkim do zależności między doświadczeniem zbiorowym a indywidualnym, stającym się znaczącym przejawem osobistego 
zaangażowania (della Porta \& Diani, 2009, ss. 100-101). Dla aktywistek Femenu tożsamość członkini ruchu była jedną z istotniejszych, na które się powoływały - bycie "femenką" jest dla założycielek praktycznie całym życiem, a dla szeregowych działaczek przynajmniej dużą jego częścią. W Femenie odnalazły się ze swoimi poglądami i ideami, spotkały innych ludzi, którzy myślą tak samo; przynależność do ruchu jest dla wielu naturalną konsekwencją życiowych poszukiwań, pewną ciągłością dążeń i społecznej aktywności.

Zagraniczne oddziały Femen powstają właśnie na zasadzie nieformalnych sieci kontaktów i współdzieleniu poglądów, z zachowaniem jednak autonomii i niezależności. Główna aktywistka i założycielka Femen Brazil, Sara Winter, dowiedziała się o akcjach ukraińskiego Femenu przez internet, w taki sposób skontaktowała się też z kijowskimi aktywistkami, a przed Euro 2012 przyjechała do Kijowa na "szkolenie”, by wziąć udział w kilku akcjach i zobaczyć, jak Femen organizuje swoją działalność, jak przygotowuje i przeprowadza akcje itp. Tak opisywała najczęstszy sposób rekrutacji aktywistek Sasza Szewczenko:

Ja: A jak odbywa się nabór?

Sasza Szewczenko: Znajdują nas w sieciach społecznościowych. Wykazują chęć zostania aktywistką, biorą udział w akcjach albo robią z początku chociaż fotoakcje, na przykład jak aktywistka z Brazylii. Ona zrobiła sobie zdjęcie w wianku [...]. Przysłała nam zdjęcie, no i teraz ona przyjedzie na Euro 2012 i będzie brać udział w akcjach tu, w Ukrainie (wyw. autorki)

Aktywistkę Sarę spotkałam w czasie jej podróży do Kijowa przez Warszawę w czerwcu 2012 r. Miałam wówczas okazję z nią porozmawiać o tym, dlaczego chce stworzyć w rodzinnym Sao Paulo oddział Femenu. Jej główną motywacją okazały się głośne medialnie i radykalne obyczajowo protesty, które przyniosły ukraińskiemu Femenowi taką popularność i rozpoznawalność. Już wcześniej - przed wizytą w Kijowie - używała ona nazwy „Femen Brazil” (taką nazwę nosi strona na Facebooku, którą już wcześniej prowadziła) na użytek swoich akcji i identyfikowała się szeroko jako członkini tego ruchu. Taka jest też idea Femenu: użycza on swojej nazwy, by firmować to, co mieści się w bardzo szeroko pojętej walce z patriarchatem, walce o prawa kobiet. Można by to nazwać swoistą "franczyzą" marki Femen - użycza ona swojej rozpoznawalnej już na świecie nazwy oraz know-how, w zamian za rozprzestrzenianie ideologii ruchu. Te zagraniczne „oddziały" Femenu nie są duże, najczęściej składają się z kilku-kilkunastu dziewczyn (często jest to trudne do ustalenia, jako że nie ma oficjalnego kryterium członkostwa, a aktywistki poświęcają na działalność w ruchu tyle czasu, na ile pozwalają im inne obowiązki). Podobnie powstały oddziały Femen Canada, Femen Tunisia czy Femen India. Przykładem może być również raczkujący polski oddział Femenu - siłą 
napędową jest tu przede wszystkim jedna zaangażowana osoba, która starała się uzyskać od "oryginalnego" Femenu rady organizacyjne (głównie poprzez wymianę e-maili), ale same akcje, ich cele i formalne szczegóły grupa ustalała na miejscu, w Warszawie, bez konsultacji z ukraińskimi założycielkami. Wyjątkiem są dwa "oficjalne" zagraniczne oddziały Femenu założone w Paryżu i Berlinie, którym przewodzą dwie z ukraińskich założycielek - odpowiednio Inna i Sasza. Te oddziały, jako „oficjalne”, są lepiej zorganizowane, a ich akcje są bardziej widoczne w mediach dzięki wrażeniu „autentyczności”, której nadają im „oryginalne”, ukraińskie liderki. Przy otwarciu oddziału w Berlinie Femen zakomunikował na swojej oficjalnej stronie:

"Międzynarodowy kobiecy ruch FEMEN ogłasza otwarcie narodowej grupy sekstremistek w Niemczech. Grupa trenerek prowadzona przez słyną aktywistkę FEMEN Aleksandrę Szewczenko przeniosła się do Niemiec, aby tam budować ruch. Miejscem będzie stolica Niemiec - Berlin oraz centrum niemieckiego przemysłu seksualnego, miasto portowe Hamburg. Powodem utworzenia oddziału ruchu stała się rosnąca liczba kobiet, które są gotowe walczyć o prawa kobiet oraz wypowiedzieć wojnę przemysłowi seksualnemu, kościołowi oraz innym średniowiecznym formom kobiecego niewolnictwa. Jesteśmy pełne optymizmu z powodu sukcesu FEMEN France, ruchu organizowanego przez Innę Szewczenko - jedną z 20 kobiet-ikon roku 2012 w rankingu wpływowej gazety Le Figaro. FEMEN Germany jest trzecim narodowym oddziałem FEMENu, który działa oficjalnie. Brazylijskie, Tunezyjskie, Amerykańskie narodowe oddziały sekstremistek będą następne ${ }^{\prime \prime 2}$.

Choć obowiązuje dyscyplina w ramach realizacji wyznaczonych założeń, np. danego oddziału, to nikt odgórnie nie reguluje, jakimi sprawami powinny zajmować się aktywistki w poszczególnych krajach, nie ma nad członkiniami stałego nadzoru ani odgórnego przymusu. Członkinie miejscowych oddziałów Femenu same decydują, co jest ważną lokalnie kwestią, którą należy poruszyć, a od twórczyń pierwotnego Femenu czerpią inspirację, metody i ugruntowane już w społecznej świadomości symbole (jak np. wianki). $Z$ drugiej jednak strony te nieformalne sieci są zebrane pod jednym szyldem o nazwie Femen, muszą też zostać przez ukraiński oddział zaakceptowane i przyjęte - innych określonych zasad członkostwa nie ma. Na oficjalnej stronie ruchu, w zakładce "dołącz", znajduje się formularz, który należy wypełnić, jeśli chce się „wziąć udział w prawdziwym proteście Femen": należy podać swoje imię, adres e-mail, wiek, kraj, miasto i umiejętności, a także załączyć zdjęcie. Po wysłaniu zgłoszenia jedna z aktywistek kontaktuje się z chętną osobą mailowo.

\footnotetext{
${ }^{12}$ http://femen.org/en/news/id/216 („FEMEN sextremists are in Germany”, 2013); oryginalny tekst na stronie jest w jęz. angielskim - przy czym składnia, ortografia i gramatyka większości wypowiedzi Femenek publikowanych w tym języku nie jest najwyższej jakości, stąd tłumaczenie oddaje chaos i nieskładność oryginalnych wpisów.
} 
To jednak nie jedyny sposób, by stać się aktywistką Femenu; dołączyć do ruchu można także po prostu poprzez rozpoczęcie działania w swoim mieście i deklarację identyfikacji z ideałami ruchu - tak jak zrobiła to Sara w Brazylii czy działaczki w Niemczech, tak też próbują zacząć swoją działalność aktywistki z Polski.

\section{Podsumowanie}

Uważam, że Femen - między innymi dzięki umiejętnemu sterowaniu swoim wizerunkiem, sprawnemu wykorzystywaniu możliwości, jakie dają media społecznościowe i zainteresowanie mediów masowych - stał się w stosunkowo krótkim czasie zjawiskiem o zasięgu globalnym, oddziałującym realnie na rzeczywistość wokół, zarówno w wymiarze politycznym, jak i społecznym. Założycielki Femenu nieraz podkreślały, że ich celem jest działanie pod własnym sztandarem; nie tylko nie są zainteresowane współpracą z innymi organizacjami ukraińskimi, ale nie chcą też być „przejęte” przez feministki z Zachodu. W swojej szeroko zakrojonej działalności Femenki udowodniły, że chcą stać się prawdziwym ruchem społecznym, który porwie tłumy, używając haseł radykalnej kobiecej rewolucji; z tego samego powodu nie chciały angażować się we współpracę z innymi ruchami czy organizacjami np. z Francji czy Niemiec, by nie zatracić swojego charakteru, by zmiana przyszła od nich z Ukrainy, ze Wschodu, a nie odwrotnie.

Ja: Czy utrzymujecie jakieś związki z międzynarodowymi organizacjami?

Sasza Szewczenko: Nie zadajemy się z innymi kobiecymi organizacjami z zagranicy, utrzymujemy kontakt z kobietami aktywistkami, które są gotowe nazwać siebie femenkami. Teraz staramy się za pomocą internetu i Skype'a założyć tam organizacje Femenu, nie współpracować z innymi organizacjami, tylko trzymać czystą linię. Jeśli robimy topless-protest, to powinien być topless-protest. Jeśli to robi Femen, to tylko Femen. Nie chciałybyśmy wiązać się z kobietami, które wychodzą tysiącami z plakatami i balonami. One mają inne zadanie. My uważamy, że działania dla obrony praw kobiet powinny być bardziej radykalne i agresywne, tak jak my to robimy. Chcemy, żeby to były topless-aktywistki, które by wyskakiwały przed Sarkozy'ego, albo teraz Hollandem, a nie chodziły po prospektach Paryża. (wyw. autorki)

Biorąc pod uwagę tego rodzaju akcje i rozszerzenie definicji wroga społecznego (który jednak wciąż mieści się w szerokim pojęciu „patriarchatu”), wpisanie działań Femenu w logikę ruchów walczących na rzecz globalnej sprawiedliwości nie byłoby zbytnim nadużyciem, chociaż nie dociekam tu prawdziwych pobudek i celów ich aktywności - pojęcie „prawdy” w tym przypadku jest wyjątkowo trudne do zweryfikowania i wymagałoby dogłębnego 
sprawdzenia finansów ruchu i jego planów, poznania wszystkich powiązań oraz zależności między aktywistkami a sponsorami, politykami i innymi społecznymi aktorami itp., co znajdowało się poza moim zasięgiem (jak i poza zasięgiem większości szeregowych aktywistek). Nawiązując w tym miejscu do kategorii „prawdy”, chciałabym zaznaczyć, że konsekwentnie traktując Femen jako ruch społeczny, uznaję za Manuelem Castellsem, że „są one tym, czym głoszą że są" (Castells, 2008, s. 77), to znaczy, że ich praktyki dyskursywne (i nie tylko) stanowią próbę przypisania sprawczości i nadania podmiotowości swojemu ruchowi, a pośrednio sobie, że funkcjonują trochę na zasadzie zaklinania rzeczywistości - Femen chce być globalnym ruchem kobiecego protestu i, co więcej, robi wszystko, co możliwe, aby to osiągnąć.

\section{Bibliografia}

Castells, M. (2008). Siła tożsamości. (S. Szymański, Tłum.). Warszawa: Wydawnictwo Naukowe PWN.

Della Porta, D., \& Diani, M. (2009). Ruchy społeczne: wprowadzenie. (A. Sadza, Tłum.). Kraków: Wydawnictwo Uniwersytetu Jagiellońskiego.

FEMEN. (b.d.-a). Pobrano 22 października 2013, z http://femen.info/pro-projekt/

FEMEN. (b.d.-b). Pobrano 22 grudnia 2013, z http://femen.org/about

FEMEN sextremists are in Germany. (2013, styczeń 24). Pobrano 8 września 2014, z http:// femen.org/en/news/id/216

Femen's topless warriors start boot camp for global feminism. (2012, wrzesień 22). The Guardian. Pobrano 8 września 2014, z http://www.guardian.co.uk/world/2012/sep/22/femen-topless-warriors-global-feminism

FEMEN took over feminism. (b.d.). Pobrano z http://femen.info/femen-took-over-femenism/ Hammersley, M., \& Atkinson, P. (2000). Metody badań terenowych. (S. Dymczak, Tłum.). Poznań: Zysk i S-ka.

Kaźmierkiewicz, P. (2012). Stan ukraińskiego społeczeństwa obywatelskiego - próba diagnozy. W P. Laufer (Red.), Raport o stanie kultury i NGO w Ukrainie. Lublin: Episteme.

Kiś, O. (2012). Feminizm we współczesnej Ukrainie: od „alergii” do ostatniej nadziei. Kultura Enter. Pobrano 8 września 2014, z http://kulturaenter.pl/feminizm-we-wspolczesnej-ukrainie/2013/03/

Kohut, A. (2012). Ukraińskie społeczeństwo obywatelskie 2012 - w poszukiwaniach alternatywy. W P. Laufer (Red.), Raport o stanie kultury i NGO w Ukrainie. Lublin: Episteme.

Majerczyk, M., \& Płachotnik, O. (2011). Radykalny Femen i nowy kobiecy aktywizm. Kultura Enter. Pobrano 8 września 2014, z http://kulturaenter.pl/radykalny-\%E2\%80\%9Efemen\%E2\%80\%9Di-nowy-kobiecy-aktywizm/2011/05/

Marketplace of Ideas Theory. (b.d.). Pobrano 8 września 2014, z http://uscivilliberties.org/ themes/4099-marketplace-of-ideas-theory.html 
Merleau-Ponty, M. (2001). Doświadczenie ciała i klasyczna psychologia. Przestrzenność ciała własnego i motoryczność. W M. Kowalska \& J. Migasiński (Tłum.), Fenomenologia percepcji. Warszawa: Aletheia.

Mrijemo wywesty na wulicu tysjaczi ogolonych żinok. (2012). Polityczna Krytyka. Seks i polityka, $3,49-52$.

Paleczny, T. (2010). Nowe ruchy społeczne. Kraków: Wydawnictwo Uniwersytetu Jagiellońskiego.

Pichardo, N. A. (1997). New Social Movements: A Critical Review. Annual Review of Sociology, 23(1), 411-430. doi:10.1146/annurev.soc.23.1.411

Płachotnik, O. (2012). Niewiarygodne przygody teorii gender na Ukrainie. Kultura Enter. Pobrano 8 września 2014, z http://kulturaenter.pl/niewiarygodne-przygody-teorii-gender-na-ukrainie/2012/05/

Sasson-Levy, O., \& Rapoport, T. (2003). Body, Gender, and Knowledge in Protest Movements: The Israeli Case. Gender \& Society, 17(3), 379-403. doi:10.1177/0891243203017003006

Touraine, A. (2010). O socjologii. (M. Warchala, Tłum.). Warszawa: Wydawnictwo Naukowe PWN. Tyszczenko, J., \& Bakalczuk, W. (2012). Organizacje pozarządowe a władza: pomiędzy tożsamością, kulturą i polityką. W P. Laufer (Red.), Raport o stanie kultury i NGO w Ukrainie. Lublin: Episteme.

Wawrzyńczyk, J. (Red.). (2008). Nowy słownik rosyjsko-polski, polsko-rosyjski. Warszawa: PWN. Wieviorka, M. (2011). Dziewięć wykładów z socjologii. (A. Trąbka, Tłum.). Kraków: Nomos.

Zychowicz, J. (2011). Two Bad Words: FEMEN \& Feminism in Independent Ukraine. Anthropology of East Europe Review, 29(2).

Закон України про громадські об'єднання. (b.d.). Pobrano 20 grudnia 2013, z http://zakon2. rada.gov.ua/laws/show/4572-vi

\section{Bibliography}

Castells, M. (2008). Siła tożsamości. (S. Szymański, Trans.). Warszawa: Wydawnictwo Naukowe PWN.

Della Porta, D., \& Diani, M. (2009). Ruchy społeczne: wprowadzenie. (A. Sadza, Trans.). Kraków: Wydawnictwo Uniwersytetu Jagiellońskiego.

FEMEN. (n.d.-a). Retrieved October 22, 2013, from http://femen.info/pro-projekt/

FEMEN. (n.d.-b). Retrieved December 22, 2013, from http://femen.org/about

FEMEN sextremists are in Germany. (2013, January 24). Retrieved September 8, 2014, from http://femen.org/en/news/id/216

Femen's topless warriors start boot camp for global feminism. (2012, September 22). The Guardian. Retrieved September 8, 2014, from http://www.guardian.co.uk/world/2012/sep/22/ femen-topless-warriors-global-feminism 
FEMEN took over feminism. (n.d.). Retrieved from http://femen.info/femen-took-over-femenism/ Hammersley, M., \& Atkinson, P. (2000). Metody badań terenowych. (S. Dymczak, Trans.). Poznań: Zysk i S-ka.

Kaźmierkiewicz, P. (2012). Stan ukraińskiego społeczeństwa obywatelskiego - próba diagnozy. In P. Laufer (Ed.), Raport o stanie kultury i NGO w Ukrainie. Lublin: Episteme.

Kiś, O. (2012). Feminizm we współczesnej Ukrainie: od „alergii” do ostatniej nadziei. Kultura Enter. Retrieved September 8, 2014, from http://kulturaenter.pl/feminizm-we-wspolczesnejukrainie/2013/03/

Kohut, A. (2012). Ukraińskie społeczeństwo obywatelskie 2012 - w poszukiwaniach alternatywy. In P. Laufer (Ed.), Raport o stanie kultury i NGO w Ukrainie. Lublin: Episteme.

Majerczyk, M., \& Płachotnik, O. (2011). Radykalny Femen i nowy kobiecy aktywizm. Kultura Enter. Retrieved September 8, 2014, from http://kulturaenter.pl/radykalny\%E2\%80\%9Efemen\%E2\%80\%9D-i-nowy-kobiecy-aktywizm/2011/05/

Marketplace of Ideas Theory. (n.d.). Retrieved September 8, 2014, from http://uscivilliberties. org/themes/4099-marketplace-of-ideas-theory.html

Merleau-Ponty, M. (2001). Doświadczenie ciała i klasyczna psychologia. Przestrzenność ciała własnego i motoryczność. In M. Kowalska \& J. Migasiński (Trans.), Fenomenologia percepcji. Warszawa: Aletheia.

Mrijemo wywesty na wulicu tysjaczi ogolonych żinok. (2012). Polityczna Krytyka. Seks i Polityka, 3, 49-52.

Paleczny, T. (2010). Nowe ruchy społeczne. Kraków: Wydawnictwo Uniwersytetu Jagiellońskiego.

Pichardo, N. A. (1997). New Social Movements: A Critical Review. Annual Review of Sociology, 23(1), 411-430. doi:10.1146/annurev.soc.23.1.411

Płachotnik, O. (2012). Niewiarygodne przygody teorii gender na Ukrainie. Kultura Enter. Retrieved September 8, 2014, from http://kulturaenter.pl/niewiarygodne-przygody-teoriigender-na-ukrainie/2012/05/

Sasson-Levy, O., \& Rapoport, T. (2003). Body, Gender, and Knowledge in Protest Movements: The Israeli Case. Gender \& Society, 17(3), 379-403. doi:10.1177/0891243203017003006

Touraine, A. (2010). O socjologii. (M. Warchala, Trans.). Warszawa: Wydawnictwo Naukowe PWN. Tyszczenko, J., \& Bakalczuk, W. (2012). Organizacje pozarządowe a władza: pomiędzy tożsamością, kulturą i polityką. In P. Laufer (Ed.), Raport o stanie kultury i NGO w Ukrainie. Lublin: Episteme.

Wawrzyńczyk, J. (Ed.). (2008). Nowy słownik rosyjsko-polski, polsko-rosyjski. Warszawa: PWN. Wieviorka, M. (2011). Dziewięć wykładów z socjologii. (A. Trąbka, Trans.). Kraków: Nomos.

Zakon Ukraïny pro hromads'ki ob'iednannia. (n.d.). Retrieved December 20, 2013, from http:// zakon2.rada.gov.ua/laws/show/4572-vi

Zychowicz, J. (2011). Two Bad Words: FEMEN \& Feminism in Independent Ukraine. Anthropology of East Europe Review, 29(2). 


\title{
Popfeminizm w służbie rewolucji. Ruchy kobiece i praktyki protestu na przykładzie ukraińskiej grupy Femen
}

\begin{abstract}
W pracy pochylam się nad ukraińskim ruchem protestu Femen, kontekstem jego powstania, rozwoju i działalności - początkowo w Ukrainie, a potem także w Europie Zachodniej. Analizuję charakter grupy jako należącej do kategorii nowych ruchów społecznych, a także przedstawiam i analizuję przejawy działań kontestacyjnych ruchu, opartych o konwencję performance'u i przedstawień ulicznych. Przedmiotem mojego zastanowienia jest także kwestia obecności oraz funkcjonowania przedstawicielek Femenu w mediach (nowych oraz tradycyjnych) oraz wpływów popkultury na różne przejawy jego aktywności. Rozważam także kwestię wykorzystania nagości w sferze publicznej, powiązaną z użyciem idiomu narodowościowego, w kontekście innych ruchów feministycznych.
\end{abstract}

\section{Słowa kluczowe:}

Femen; ruch społeczny; protest; nagość; feminizm; Ukraina; rewolucja feministyczna; popkultura; ukraińskość

\section{Pop feminism in the service of revolution. Women's movements and practices of protest: Ukrainian group Femen case study}

In my paper I take a close look at the protest group, Femen, the circumstances of its creation, development and recent activities - initially in Ukraine, latterly also in Western Europe. I analyse the character of the group which belongs to the category of new social movements, and I present and analyse those indications of the activity of demonstrations of the movement based on what took place at street level. The object of my interest is also the issue of the appearance of the representatives of Femen in the media (new and traditional) and the influence of the pop culture on different aspects of its activity. I also question the issue of the employment of nudity in the public domain, and its connection with the usage of the expression of nationality against the background of other feminist movements.

\section{Keywords:}

Femen; social movement; protest; nudity; feminism; Ukraine; feminist revolution; pop culture; ukrainity 